\title{
Background Information: Isolation Routines
}

\subsection{Isolation}

The isolation of patients with suspected or documented infections- to not spread to others-has been discussed for hundreds of years. Guidelines are many, methods are different, attitudes show vide variations, routines and procedures are still changing, regulations by law may be absent, and some healthcare professionals may be afraid of adverse outcomes of isolation [1-44]. Microbes that are spread in the environment, on the hands and equipment are invisible. The invisible agent does not call on attention before the infection; clinical disease, hospital infection or nosocomial infection is a factum that can be registered [23, 28, 29, 35-37]. How to stop the transmission is often "to believe and not believe" in infection control.

\subsection{History}

Isolation comes from the Latin word isolare, from solus meaning alone. Isola means a "deserted" island, including Isola outside Venice, Isola di Santa Maria di Nazareth, where the first permanent quarantine hospital-nazaretto changed to Lazaretto (Lazarus) — was created in 1423 [45]. It was the bubonic plague or the Black Death (1347-1352) and leprosy which triggered the need for isolation or quarantine that protected against people who were sick. Quarantine (from Italian quaranta $=40$ ) was introduced in Southern Europe ca. year 1400, to isolate presumed infectious ships, persons, goods, food and equipment from other places at quarantine stations for 40 days, i.e. double the incubation period for most serious infectious diseases, also in our time.

In Norway, isolation was created primarily for leprous patients, probably by King Magnus Lagabøter in Bergen, ca. 1270, later on for the Black Death (approximately 1350), the white plague; tuberculosis, from the mid-1800s, at sanatoriums 
like Luster in Sogn and Glitre in Akershus or in separate isolation buildings at the hospital, like epidemic buildings at Ullevål Hospital.

Despite academic controversy about "infection or not" from the late 1700s to the 1860 s, the isolation treatment was used for presumably "infectious diseases" like typhoid, cholera, scarlet fever, diphtheria, smallpox, plague, etc. Patients were isolated in hospital, at home or in own local epidemic houses in the country. Chronic carriers of typhoid bacteria (Salmonella typhi) were isolated alone at home or at the counties epidemic house by themselves (Smitteborg, "infection castle" in Skreia, Norway, is still a local name). The epidemic houses had access control and were monitored by the healthcare board mayor. Hygiene and infection control were very important since they had few curative agents. It was prepared vaccines and carried out partly or complete mass vaccinations against some infections.

Pulmonary tuberculosis was treated at sanatoriums in the mountains or at coast hospitals. The patient did not come home until he was free from infection. During outbreaks of typhoid fever, diphtheria or scarlet fever, the patients were isolated in separate sick barracks or at home. To be a carrier of an infectious disease could lead to work prohibition and isolation. Schools were closed intermittently during outbreaks, and posters were put on houses with infectious disease as a warning. Disinfection of houses, clothing and all of its contents was completed after the termination of the isolation period, using chlorine and sulphur smoke. Carbolic acid and hydrochloric acid were also used where sulphur fumes treatment failed. Bedding, clothing and fixtures that could not be washed or disinfected were often burned, with a financial compensation for this "outlay." Patients who broke the isolation routines could be penalized and committed to further isolation. The society's need went first before each individual's needs [46].

During the 20 years from 1911 to 1930 , among approximately 2.4 million inhabitants in Norway, there were a total of 2,146,702 cases of acute laryngitis and bronchitis, 470,099 with acute gastroenteritis, 181,752 with "croup pneumonia," 89,100 cases of diphtheria, 75,000 with scarlet fever, 71,000 with rheumatic fever, 15,000 with typhoid and paratyphoid fever, 5300 with poliomyelitis and 3200 with dysentery! [46]

Knowledge of infection, sanitation and housing conditions (less overcrowded), clean water, good personal hygiene, vaccinations and nutritional status were factors mitigating epidemic outbreaks beginning of the twentieth century. This demonstrates that most infectious diseases can be prevented and controlled, even without antibiotics.

In 1937, before the breakthrough of the penicillin, there were the most important precautions against infectious diseases in Norway: [1] isolation of the source of infection, [2] disinfection, [3] vaccination, [4] quarantine, [5] food hygiene and [6] eradication of insects [46]. Airborne infection was estimated as "the most important form of spreading infections" which may be correct even today [46, 47].

The last 125 years of isolation treatment carried out in Norway have been in separate houses and buildings until ca. 1960 when most infectious diseases were integrated into appropriate wards for the underlying diseases. In 1970 there was still 
isolate buildings where all kinds of infections were taken care of and with good routines. Today, this type of isolation is gone, with exception of some buildings in preparedness for strict isolation.

\subsection{Hospital Infections that Should Be Treated in Isolates}

In each third to fifth hospital bed, there is an infected patient, and each third patient is treated with resistance-driving antibiotics today [28, 29, 35, 48]. Isolation units are therefore of great need.

In Norway with 5.5 million inhabitants, ca. 900,000 patients are treated annually in hospitals and about 50,000 receive hospital infections, resulting in at least 450,000 extra days in hospitals because of infection. Hospital infections with Staphylococcus aureus occur in $2 \%$ of the patients [28, 29]. Isolation treatment is laborious and expensive (ca. 10,000 NKR or 1400 USD per day). Out of the 13,700 somatic beds in Norway in 2013, hospital infections charged ca. $20 \%$ of these, which would generate a need for ca. 2740 infection beds. However, the somatic bed capacity in Norway is steadily being reduced, which creates several problems in the healthcare.

\subsection{New and Old Microbes Increase the Need for Isolates}

There is an increased need of isolates for patients with infections, especially due to pulmonary tuberculosis, MRSA, VRE, Clostridium difficile (CD), multiresistant gram-negative bacteria and other "multidrug-resistant organisms" (MDRO) [23, 24, 36, 37, 48-51]. Global incidence of entero-pathogenic bacteria and imported resistant agents increases, and there is an ongoing microbial spread via food, animals, fish, water, supplies and the environment $[48,51]$.

New knowledge of transmission, robustness and ability to survive in the environment may reinforce the methods for isolation. CD, originally defined as contact transmission, may also spread through the air [52]. CD problem increases, particularly in the United States where half a million patients are infected each year and 29,000 of them died in 2011 [53]. A special dangerous CD type (NAP1) is detected [53].

The incidence of new respiratory viruses like Human metapneumovirus, bocavirus, Human coronavirus, etc. increases. For the first time in more than 100 years, a highly pathogenic virus as Ebola has been introduced to Norway and to other countries in Europe. Pandemic-actual viruses such as SARS, MERS, different types of bird flu, new outbreaks of Ebola and other viral haemorrhagic fevers show the need for isolation and emergency preparedness [30-34].

Children's diseases, who disappeared with vaccinations, like whooping cough, mumps, rubella and measles, are now increasing with outbreaks in areas with high vaccination rate in America and Europe [1]. From 2014 to 2015, Europe had more 
than 22,000 measles cases [54]. By hospitalization, these need airborne infection isolation units.

Noro-, rota- and sapoviruses and other types of virus gastroenteritis are highly infectious with vomiting and producing of aerosols, i.e. airborne infection. Growing global outbreaks of norovirus may cause fast and widely spread of gastroenteritis among patients and personnel in health institutions and cause inactivity and stop of new admissions $[55,56]$.

\subsection{Particular Issues Around Infection and Isolation}

The closure of wards or hospitals. Outbreaks often end with the closure of the ward, as shown in one study, median in 14 days [16]. Geriatric wards are usually closed during outbreaks. The most frequent cause is outbreaks of norovirus, $44 \%, p<0.001$ and influenza/parainfluenza, 38.5\%, $p<0.001$ [16].

Intensive care units (ICU) are often particularly vulnerable to infection. Crosscontamination between such patients is normal [57]. In a 16-bed ICU for adults, 430 patients were followed for 3950 patient days and cross-transmission was followed by genetic typing of the microbes [57]. A total of 40 episodes of cross-transmission was demonstrated and dominated by Pseudomonas aeruginosa, other gram-negative bacilli and $S$ aureus. Cross-transmission was associated with understaffing, use of nasogastric tube, ventilator and other multiple patient-to-nurse contacts and immune-compromised patients [57]. Patients treated at understaffed ICUs were three times more likely to be infected; immunosuppressed had four times greater risk, and bronchoscopy-treated patients led five times higher risk [57]. Intensive units often have no isolates, and if they have, they are not so much used because of staff shortages.

\subsection{Lack of Infection Isolates}

Airborne infection isolation units will quickly be economic by more control over the spread of infection, fewer extra days in hospitals and fewer sick leave for personnel, as was demonstrated during the SARS epidemic [33]. The larger outbreaks of infectious childhood diseases require more isolation for airborne infections [58]. The same goes for whooping cough which 10 years ago was an unknown phenomenon in Norway and now in widespread child and adult disease [59]. Imported infections are increasing, and hospital infections like wound infections, respiratory tract infections and antibiotic-associated diseases are also increasing.

In the 1980s, the State Board of Health in Norway recommended that the number of isolation beds should be $10 \%$ of the hospital's total bed numbers and the ICU $25 \%$ [60]. At Ullevål Hospital, 5\% of the beds were airborne infection isolates, and $3 \%$ contact isolates in 2008 [22, 28, 29]. 


\subsubsection{Airborne Infection Isolation Units: "High-Level Isolation Rooms"}

In 2009, a European investigation was done as regards the number of "high-level isolation rooms" (HIRs), i.e. airborne infection isolation units with negative pressure (not defined) with at least 6 air changes per hour and sluice (anteroom) [61]. This is a unit intended for high- risk infections like haemorrhagic viral infection, SARS, the starting phase of pandemic influenza, XDR (extended drug-resistant) tuberculosis, anthrax, plague, biological terrorism, etc. [61]

In all, 16 European network countries (EUNID) with 211 hospitals and about 1790 isolation beds participated. Many of these had fewer than 6 air changes per hour [61]. The total proportion of airborne infection isolates (HIR) per country were calculated per million inhabitants. The largest proportion of these isolation units were detected in Luxemburg, 31.5 per million; followed by Finland, 28.4; Sweden, 25.9; Ireland, 15.1; Denmark, 14.3; Italy, 12.3; and Estonia, 11.2 per million inhabitants. Spain, the Netherlands, Germany and the United Kingdom had the lowest share, $0.2,0.2,0.3$ and 1.7 per million inhabitants, respectively [61].

Most countries used HEPA filter for air extraction from the isolates (9 out of 11). Among 13 countries, 4 had localized airborne isolates (HIR) to own buildings or wards, in 4 was HIR in the same ward as other patient rooms, and in 5 both solutions were adopted [61]. A total of 342 HIRs were equipped for intensive care, most in Italy ( 245 beds) and in Denmark (40 portable beds) [61].

After year 2000, HIRs have been used in Europe to approximately 10 imported haemorrhagic fever cases and 33 confirmed SARS cases.

In the United States, there are three "high-level isolation units" (HLIU), placed at the same level as laboratory with biosafety level (BSL) 3 and 4, in separate buildings, with limited and controlled access, negative air pressure and special treatment of sewage and garbage [62].

\subsubsection{Isolate: Design and Function}

Isolates rely on "evidence-based design," i.e. knowledge of the construction, design, materials, equipment, furnishing, standards, etc., which are considered as core elements of the infection prevention [63]. Solid evidence of the spread of infection is used to control good environmental measures, disinfection and proper use of the isolates [64-66].

Infection isolation involves admittance of the patient to a separate room with disinfection/bathroom, sluice or anteroom (see Fig. 21.1). It is always an advantage with some negative pressure of infection isolates-even for contact infection- to avoid spread of infections outside the isolate.

A contact isolate has sluice, patient room and disinfection/bathroom, about. $35 \mathrm{~m}^{2}$. The sluice should be at least $6 \mathrm{~m}^{2}$ with room for bed or stretcher and wash 


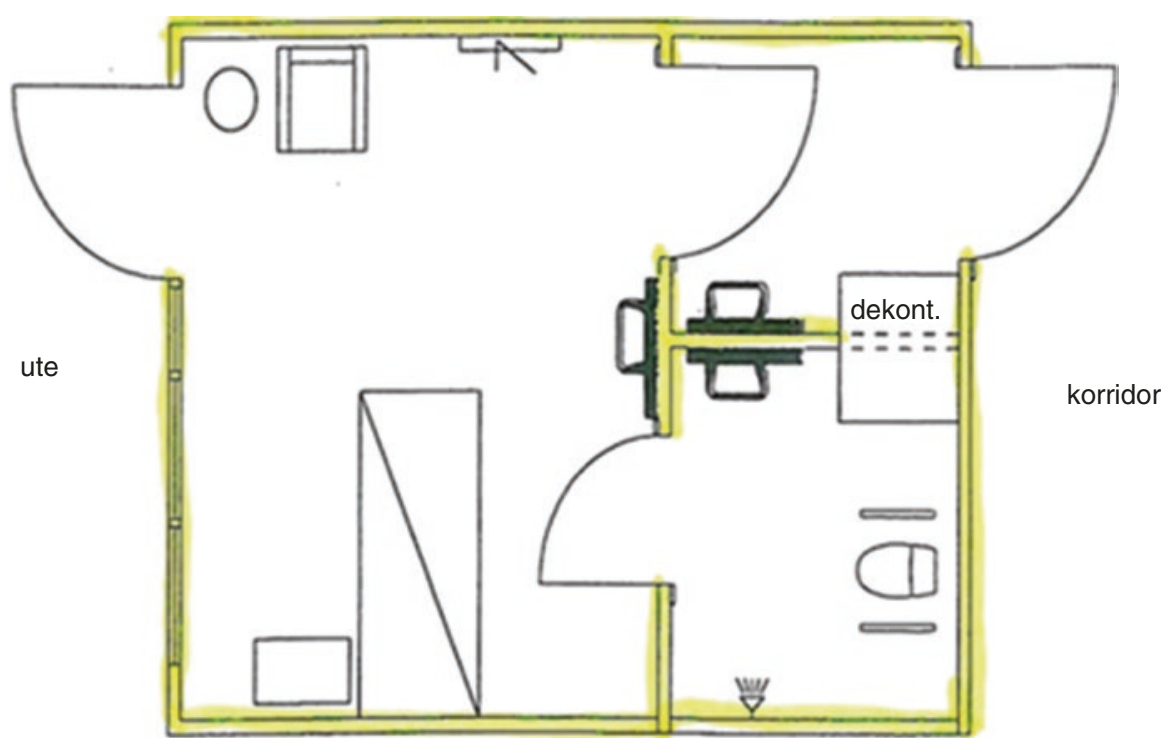

Fig. 21.1 Isolation unit with sluice, patient room, bathroom, throughput decontaminator. Source: BM Andersen. Handbook in hygiene and infection control for nursing homes and long-term care facilities 2013, Akademika Forlag, Oslo

basin. It shall have a defined clean side, space for clean clothes and unused PPE and a dirty side, for infectious waste and infectious waste bags or containers.

Patient room should be at least $20 \mathrm{~m}^{2}$, with the head end against the wall and about $2 \mathrm{~m}$ free zone on both long sides and from the foot end, to avoid too close contact with the patient.

Disinfection room, combined with bathroom, 8-10 $\mathrm{m}^{2}$, contains shower, toilet and wash basin, with plenty of space to be able to help the patient as needed. It should also be equipped with decontaminator, preferably a well-sealed, throughput decontaminator from disinfection room to the sluice. In throughput decontaminators (or autoclaves), infected equipment can be put in from the disinfection room and removed decontaminated in the sluice. All throughput systems should be assured with complete sealing against air leakage. It should only be opened from one side at the time, i.e. interlock. Avoid throughput cabinets between the sluice and disinfection room.

All isolation unit surfaces must be smooth, robust and withstand disinfectants, both liquid and dry gaseous form. Avoid tiles, gaps and joints where dirt can form the basis for growth and biofilms of microbes which may prevent effect of disinfection.

There should be at least eight air changes per hour ( $>$ six air changes [61]), which is important to remove the infectious agent in the room air. Incoming air must enter on the wall or ceiling; air extraction shall go out by the floor (15 cm above), preferably in the disinfection room. The isolate should have separate ventilation system so 
that the infection does not come across to other patients by setbacks in joint ventilation ducts. Intake air should be a certain distance from the air outlet. HEPA filters should be set on air outlet, and procedures for maintenance and control should be established.

Airborne infection isolate is provided and formed as for a contact isolate. The isolate should be organized for direct access from outside. In addition, the controlled and defined negative pressure is graded down from the sluice to the disinfection-bathroom compartment [22]. Pressure is usually, -16 to -25 pascal relative to the corridor and the adjacent rooms. In the sluice there is 6-10 pascal, in the patient room -16 to -25 pascal and disinfection room -25 pascal. The air will then be drawn from the cleanest room (sluice) to the dirtiest room (disinfection room), if the doors are closed.

The most stable, controlled negative pressure may be made by doors opened outwards from the patient room to the sluice and further from the sluice to the corridor (see Fig. 21.1). The vacuum will suck the door even tighter to the door frame to hinder air leakage. Interlocked doors should be used so that only one door at a time may be opened into the patient room. The stability is dependent on the number of air changes per hour. The minimum and most stabile is 6 air changes per hour (6-12) $[19,22,61]$. Each air exchange reduces the pathogenic agents in the air substantially. All air expelled exits at the floor (15 cm above) and is gathered into an outgoing ventilation channel from the disinfection compartment. Avoid "shortcuts" of the air circulation.

As for contact isolates, airborne infection isolates should have separate ventilation systems with no setbacks in ventilation ducts; external intake of air over the roof should be well away from the external air outlet over the roof, and all air from the unit is HEPA filtrated. Procedures for maintenance, disinfection and control of filters and ducts should be established.

Cohort isolation of several patients with the same infectious agent may be appropriate. It is a good initiative during pandemics. The SARS epidemic released a rapid learning process where the Chinese built-within a week-a dedicated SARS hospital for 1000 patients in Beijing [33]. In a study from Brazil, all patients with proven MDROs (multidrug-resistant organisms) were transferred to a 34-bed unit for isolation treatment by a trained personnel, where personnel, patients and family were weekly taught about how to handle MDRO's by a special team [67]. After the intervention, the MDRO rate was significantly reduced, specially by the reduction of VRE. Isolated patients had at least the same good treatment quality as not isolated patients [67]. In Norway, cohort isolation was utilized in Trondheim during the first national outbreak of MRSA (1970-1974). A total of 144 patients were infected (including 15 personnel), and 48 died $(31.6 \%)$ directly or indirectly from the hospital epidemic [68]. The control of the outbreak came first when infected patients and personnel were cohort isolated in a separate isolation ward [68].

Barrier care of one infectious patient among other patients without infections on the same bedroom in dormitory is not recommended. 


\subsubsection{Disinfection and Cleaning}

A good standard of patient isolates depends on good daily cleaning and a thorough disinfection by termination of the isolation. Long-time surviving bacteria, viruses and fungi should not be a risk for the next patient to be isolated, which may happen [69, 70]. MRSA, multiresistant Acinetobacter baumannii and other MDROs are contaminating bedding, bed and environment for months, if not removed [71].

Disinfection of rooms and isolates are often not well enough done [64]. The terminal disinfection, removal and disinfection of all equipment in the room and disinfecting of all surfaces are important. Disinfectants (liquid) that are effective against all microbial agents are chloramine $5 \%$, household bleach $10 \%$ or peracetic acid for $1 \mathrm{~h}$. Treatment with hot water $\left(>85^{\circ} \mathrm{C}\right)$ for $10 \mathrm{~min}$ is a very effective disinfection of equipment and textiles. Different types of gas or steam disinfection (hydrogen-peroxide dry gas, chlorine gas, formaldehyde gas) may be effective for equipment and room disinfection [72-75]. Note that there is yet no gas treatment that is documented to kill Mycobacteria [76].

\subsubsection{Proper Patient in the Right Place}

The isolates are often used incorrectly. In the same ward and at the same time, patients without infection are placed on the isolates while infectious patients are not isolated. Although defined isolate treatment is determined and PPE used, it turns out that the patient is walking freely around in the ward, not really isolated. Knowledge and practices increases understanding of disease control measures.

Some patients that are both prone to infection and have serious infections, like cystic fibrosis patients, should be treated in isolates [77].

\subsubsection{Side Effects of Isolation}

Depression, anxiety and anger get less visits and information by health professionals; more often fall injuries or other injuries, inferior care, etc. are claimed to be side effects of isolation [41, 43]. However, patients previously depressed and anxious at admission suffer no more under an isolation stay [39]. There is not shown differences between isolated and non-isolated patient, according to the patient's view of treatment, on the contrary [42]. But the patient satisfaction is the highest among those who are well informed [38]. Most studies show that contact time with the medical doctor is approximately equal for isolated and non-isolated patients and approximately equally frequent [40, 43]. Although MRSA or VRE infected patients, in one study, had more frequent falls and pressure ulcers, this was not reduced by removing the contact isolation, so that it was likely other factors which could contribute to such complications [78]. 


\subsubsection{Additional Costs for Transmitted Infections}

Outbreaks are very costly and take up significant resources and healthcare for other patients [79]. A patient infected with MRSA was at Ullevål University Hospital, Norway, estimated to generate an additional charge of 526,000 NKR (ca. \$75,100), including extended length, spread to a hospital employee, screening tests and antibacterial treatment in 1999 [36]. In 2002, in connection with a MRSA outbreak in neonatal ward at Ullevål, the calculated additional costs were 375,000 NKR (ca. $\$ 53,500)$ per MRSA-positive patient, including isolation expenditure, disinfection and cleaning, screening and extra days in the hospital [24]. Active screening and isolation of patients with MRSA are significantly and markedly cheaper for the healthcare than uncontrolled transmission which can result in serious infection and death [80].

\subsubsection{Anchoring Isolation Procedures in Laws, Regulations and Guidance}

Anchoring isolation procedures in laws is essential to the implementation of isolation. Norway has several laws, regulations and guidance to control infections in healthcare facilities [2-7]. International studies have laid the basis for the Norwegian isolation measures and techniques [9-14, 17-20, 27]. A number of studies regarding the design and function of isolation units exist [25, 26, 63-66]. Simply to place patients in single rooms provides noticeable improvement in the spread of infection [81].

\subsubsection{Implementation and Execution: Failing?}

The implementation of good isolation measures and compliance is often weakened by confusion, lack of written procedures, lack of training, competence and understaffing. A number of other factors also influence the attitude of healthcare professionals with regard to follow the hospital's infection control procedures, not least professional disagreement about the procedures.

- In emergency wards in the United States, only $45 \%$ of the wards used contact protection (gloves and gown) upon receipt of patients with diarrhoea or faecal incontinence, $84 \%$ for suspected CD, $49 \%$ for purulent skin infections, $79 \%$ for suspected MRSA and $63 \%$ by multiresistant gram-negative rods [21].

- It may be a big difference between what staff and others say they do and what happens in reality [82]. Among 470 persons who entered isolates, the compliance was higher by strict isolation infections $(65 \%)$ than with other infectious conditions [83]. Visitors followed the measures better than personnel (88\% versus $41 \%$ ) [83]. The compliance with isolation procedures increased significantly when more time was spent with the patient, being a visitor, and when the patient was on a strict isolation [83]. The study pointed out the danger of increased 
demands for doctors and nurses due to savings can result in adverse effects such as reduced compliance with key routines as isolation [83]. Morgan et al. observed 7750 visits of a healthcare professional to isolated and non-isolated patients. Patients on contact isolation had 36\% fewer visits and 18\% less contact, and there were fewer visitors than non-isolated patients [84]. However, the staff implemented significantly more frequent handwashing after visit in isolates, $63 \%$, than by visits with non-isolated patients, $47 \%$ [84].

- During the MRSA outbreak with ca 150 patients in Trondheim, Norway, 19701974, Kvittingen et al. described problems that may occur during epidemic and endemic conditions as "doctors more or less wholehearted support and scepticism to the measures made by the Hygiene Committee, discussions concerning the virulence and resistance development, what to do when a local outbreak paralyzes the department completely, information problems, lack of qualified personnel, etc." $[68,85]$. They stressed that "larger hospitals should dispose well-planned isolation opportunities, both for patients who are infectious spreaders and perhaps equally important, to protect patients with reduced infection defence," and that "personnel in management positions (should) provide effective and loyal support for infection control personnel" [68].

- This was a very important observation done for more than 40 years ago. It is still causing major problems during outbreaks and endemic situations when there may be a choice between shortcut thoughts about "economy" and infection control. Still, impression and experience is that staff working directly with the patients have great respect for contact and airborne routines, at least in Norway.

\subsubsection{Isolation Regimes and Recommendations}

Isolation regimes and interpretation of these are an almost perpetual discussion which changes with endemic and epidemic conditions, economy and guesswork. Although isolation of patients with infectious diseases has been used for hundreds of years, there is little evidence in terms of endemic conditions [19-22]. The Norwegian isolation regimes are based mostly on guidelines from CDC [9-12, 1721]. In addition, an increasing number of guidelines are focusing on special isolation factors $[19,64-66,69-73,86]$.

CDC's isolation guideline is graded from high evidence, highly recommended as the IA, to no recommendation and unresolved questions or professional disagreement [19]. Category IC is included in the legislation for patients and caregivers [19]. Classification into categories is essential for the most important infection control measures in hospitals. "These recommendations are designed to prevent transmission of infectious agents among patients and healthcare personnel in all settings where healthcare is delivered. As in other CDC/HICPAC guidelines, each recommendation is categorized on the basis of existing scientific data, theoretical rationale, applicability and, when possible, economic impact" [19]. The CDC recommendations are changed over time [9-12, 17-19]. 
$\mathrm{CDC} / \mathrm{HICPAC}$ system recommendations in categories in correspondence with investigations, theory and economic possibility; quoted [19].

\begin{tabular}{l|l}
\hline Category IA & $\begin{array}{l}\text { Strongly recommended for implementation and strongly supported by } \\
\text { well-designed experimental, clinical, } \\
\text { Or epidemiological studies }\end{array}$ \\
\hline Category IB & $\begin{array}{l}\text { Strongly recommended for implementation and supported by some } \\
\text { experimental, clinical or epidemiologic studies } \\
\text { And a strong theoretical rationale }\end{array}$ \\
\hline Category IC & $\begin{array}{l}\text { Required for implementation, as mandated by federal and/or state } \\
\text { regulation or standard }\end{array}$ \\
\hline Category II & $\begin{array}{l}\text { Suggested for implementation and supported by suggestive clinical or } \\
\text { epidemiologic studies or a theoretical rationale }\end{array}$ \\
\hline No & $\begin{array}{l}\text { Unresolved issue. Practices for which insufficient evidence or no } \\
\text { recommendation }\end{array}$ \\
\hline
\end{tabular}

Siegel JD et al. 2007 Guideline for isolation precautions

\subsection{Administrative Responsibility for Isolation Treatment}

CDC's isolation guideline refers to the administrative responsibility around isolation treatment [19]. The hospital's management is responsible for ensuring the implementation of good practical measures and to be the driving force in the hospital's infection control preparedness. This should particularly be done with regard to isolate patients, an extra burden, and also for the economy. Enough isolate capacity is to be provided in relation to citizens, patient categories, type of hospital activity and endemic/epidemic conditions. The isolates must be of good quality and design, and it should be enough airborne infection isolation units [19].

Some of the CDC-recommended administrative responsibilities are quoted here: [19]

Citation: "Healthcare organization administrators should ensure the implementation of recommendations in this section:

1. Incorporate prevention of transmission of infectious agents into the hospital's patient- and occupational safety programs. Category IB/IC.

2. Make prevention of transmission of infectious agents a priority for the healthcare organization. Provide administrative support, including fiscal and human resources for maintaining infection control programs. Category IB/IC.

3. Include prevention of healthcare-associated infections as one determinant of bedside nurse staffing levels and composition, especially in high-risk units. Category IB/IC.

4. Include infection control in daily treatment and care of patients. Category IB.

5. Delegate authority to infection control personnel or their designees (e.g., patient care unit charge nurses) for making infection control decisions concerning patient placement, transport and transfer -based precautions. Category IC. 
6. Involve infection control personnel in decisions on facility construction and design, determination of airborne isolates and protective environment capacity needs, and environmental assessments. Category IB/IC.

7. Ensure -- to provide clinical microbiology laboratory support, including a sufficient number of medical technologists trained in microbiology, ---for monitoring transmission of microorganisms, planning and conducting epidemiologic investigations, and detecting emerging pathogens. Identify resources for performing surveillance cultures, rapid diagnostic testing for viral and other selected pathogens, preparation of antimicrobial susceptibility summary reports, trend analysis, and molecular typing of clustered isolates ---- use these resources according to facility-specific epidemiologic needs, in consultation with clinical microbiologists. Category IB.

8. Provide -- resources to meet occupational health needs related to infection control -- evaluation and management of healthcare personnel with communicable infections. Category IB/IC.

9. In all areas where healthcare is delivered, provide supplies and equipment necessary for the ---Standard Precautions, including hand hygiene products and personal protective equipment (e.g., gloves, gowns, face and eye protection). Category IB/IC.

10. Provide ventilation systems required for a sufficient number of AIIRs (as determined by a risk assessment) and protective environments in healthcare facilities that provide care to patients for whom such rooms are indicated, according to published recommendations. Category IB/IC.

11. Involve infection control personnel in the selection and post-implementation evaluation of medical equipment and supplies and changes in practice that could affect the risk of HAI. Category IC.

12. Develop and implement policies and procedures to ensure that reusable patient care equipment is cleaned and reprocessed appropriately before use on another patient. Category IA/IC.

13. Develop and implement systems for early detection and management -----of potentially infectious persons at initial points of patient encounter in outpatient settings (e.g., triage areas, emergency departments, outpatient clinics, physician offices) and at the time of admission to hospitals and long-term care facilities (LTCF). Category IB.

14. Develop and implement policies and procedures to limit patient visitation by persons with signs or symptoms of a communicable infection. Screen visitors to high-risk patient care areas (e.g., oncology units, hematopoietic stem cell transplant [HSCT] units, intensive care units, other severely immune-compromised patients) for possible infection. Category IB.

15. Identify performance indicators of the effectiveness of organization-specific measures to prevent transmission of infectious agents (Standard and Transmission-Based Precautions), establish processes to monitor adherence to those performance measures and provide feedback to staff members. Category $I B$ ” [19]. Citation ended. 
A good and active hospital management is of major importance to stop the outbreak [23, 24, 37, 49, 50, 68, 87, 88]. Ransjø et al. attached the importance to the activity of the hospital management during outbreaks of multidrug-resistant microbes in Sweden [87]. In Norway, an outbreak of VRE by a dialysis department spring 2011, at Ullevål University Hospital, was expected from the department's critical building condition [23]. After great effort from the staff, the outbreak stopped within 14 days [23]. A structural rehabilitation started then, with expansion of bed numbers, assisted by the hospital management. One year later, all patients were VRE negative [23]. A number of outbreaks at Ullevål's premature intensive care unit during years have been linked to chronic understaffing, overcrowding, part-time work, lack of infection control practices and isolates, lack of information and a lack of management responsibilities [24, 37].

The responsibility of the hospital management to prevent and combat outbreaks of infection should be clearly stated in the hospital's infection control program.

\subsection{Contact Isolation: “Contact Precautions” (CP)}

CDC defines contact isolation, using gown and gloves when in contact with patients infected with resistant bacteria like MRSA and other MDROs (multidrug-resistant organisms), and single rooms are recommended [19].

Direct contact contamination occurs when microbes are transmitted from an infected person to another without the "intermediate stage" in the environment. Microbes transferred to the hands can further spread to the own mouth, nose, hair, ears, clothing, etc. [89] Healthcare personnel is likely to be a "source, vector or a victim" of infections like MRSA [90, 91].

Patients bring their own microbes into the hospital, with often large contact before a known infection [92-96]. Therefore, rapid tests are recommended where possible to detect pathogens $[80,97]$.

Indirect contact contamination happens when the microbes are transferred to an object in the environment and from there transmitted to other objects or people. Infectious patients themselves will have the agent on the body and clothes and transmit it to the environment. The undetected microbes can spread quietly and calmly in many directions via equipment, rooms, surfaces and missing/incorrect procedures [98]. This is often a large and persistent environmental problem and a threat to other patients [23, 24, 37, 49, 50, 57, 68-72, 87]. The most typical spread occurs when people with contaminated hands are depositing microbes on equipment, machinery, knobs, door handles, uniforms, other textiles, furniture, toys, etc. [89-91]

Fellow-patients on the same room are highly susceptible to infection [16, 20, 23, $24,37,57,96-99]$. Infection can be spread further via equipment (BP apparatus, stethoscope, medicine tray, blood sugar test equipment, journal, etc.) and the personnel's uniform. It is often brought to the ward office, to service rooms and to other personnel or patients. A long "domino" chain of infections may follow infectious agents not stopped by simple hygienic measures and isolation [98]. 
Contact infection may also be an airborne infection from patients coughing and sneezing by certain aerosol procedures, when cleaning the surfaces, by bedding and by strong air currents (e.g. by rapidly opening and closing doors) which dislodges dust from the lamps, shelves, etc. [44, 46, 47, 52, 100-102] Therefore, a daily good housekeeping and good routines for final disinfection in isolates is very important to reduce the burden and risk of pathogenic microbes [22, 74].

Contact infection prevention (CP)—recommended by CDC [19].

Some citations selected from Siegel et al. 2007; CDC guideline for isolation, where recommendations are in categories where IA is strongest recommendation.

Selected citations: [19] “

1. In acute care hospitals, place patients who require $\mathrm{CP}$ in a single-patient room when available. Category IB.

2. When single-patient rooms are in short supply, apply the following principles for making decisions on patient placement: ---- Place together in the same room (cohort) patients who are infected or colonized with the same pathogen--. Category IB.

3. Wear gloves whenever touching the patient's intact skin or surfaces and articles in close proximity to the patient (e.g., medical equipment, bed rails). Don gloves upon entry into the room or cubicle. Category IB.

4. Wear a gown whenever anticipating that clothing will have direct contact with the patient or potentially contaminated environmental surfaces or equipment in close proximity to the patient. Don gown upon entry into the room or cubicle. Remove gown and observe hand hygiene before leaving the patient-care environment. Category IB.

5. Patient transport. In acute care hospitals and long-term care and other residential settings, limit transport and movement of patients outside of the room to medically-necessary purposes. Category II.

6. When transport or movement in any healthcare setting is necessary, ensure that infected or colonized areas of the patient's body are contained and covered. Category II.

7. Remove and dispose of contaminated PPE and perform hand hygiene prior to transporting patients on CP. Category II.

8. Don clean PPE to handle the patient at the transport destination. Category II.

9. Handle patient-care equipment and instruments/devices according to Standard Precautions. Category IB/IC.

10. In acute care hospitals and long-term care and other residential settings, use disposable noncritical patient-care equipment (e.g., blood pressure cuffs) or implement patient-dedicated use of such equipment. If common use of equipment for multiple patients is unavoidable, clean and disinfect such equipment before use on another patient. Category IB [19]."

Selected citation ended. 


\subsection{Airborne and Droplets: Isolation}

Spread of pathogenic infectious agents through the air and droplets requires a defined negative pressure ventilation isolate and a system which reduces airborne infection in the patient's room. It is best done by air replacement 6-12 times an hour $[19,61]$.

The cause of airborne, pathogenic microbes may include:

1. Transmitted to the air from infected airways by coughing, sneezing, sputum, watery eyes, talking, shouting, singing, etc., caused by influenza, parainfluenza and other respiratory viruses, tuberculosis, staphylococci, pneumococci, gramnegative rods, etc. $[12,19,22,46,47]$

2. Transmitted to the air from infected gastrointestinal tract by vomiting, e.g. norovirus, rotavirus, sapovirus and entero-haemorrhagic E. coli (EHEC).

3. Transmitted by splash and spray from pus, blood, tissue- particles, etc. in tiny droplets, particularly during surgery, punctures, suction, diathermy, gastroscopy, etc. $[103,104]$

4. From splashes and spills by invasive, aerosol-generating procedures like bronchoscopy.

5. From accidents and spill by insertion or replacement of catheters in the blood and the urinary tract.

6. By rapid removal of the bandage from pus and discharging wounds.

7. By raise up of infected dust, skin cells and other contaminants by activities that create air currents, often in poorly cleaned rooms [44].

8. Re-aerosolized pathogens from used textiles and equipment in the patient room or where these contaminated items are brought, for instance, to the ward's disinfection room or to the laundry. By massive contamination and poor routines for washing equipment and hospital textiles, this may cause a special problem of re-aerosols [105].

9. Construction activity of all types without measures against airborne infection is influencing the airborne spread of bacteria, virus and fungi. This must be taken into account when rebuilding and repairing buildings and ventilation ducts etc. $[22,105]$. If ignored, it may cause large problems like the outbreak of Bacillus cereus among 171 patients, most with sepsis, during 6 months of a large construction project next to the hospital [105]. Air samples showed growth of large quantities of Bacillus inside the hospital, the units and also isolates, and hospital textiles were heavily contaminated [105].

On a daily basis, the human inhales 10,000 particles or more via airways; many of these are bacteria, viruses and fungi but mostly come up again without causing disease.

A solid documentation shows that airborne infection may occur at a variety of infectious diseases [12, 22, 31, 47, 52, 54, 58, 59, 85, 100-119]. Rooms with MRSA-infected cases may have larger numbers of MRSA bacteria in air samples 
than in samples from surfaces $[113,114]$. MRSA may even be spread to nearby located rooms, to patients not infected $[113,114]$. The few existing units for airborne infection isolation mean that most patients, except for pulmonary tuberculosis, most often are admitted to contact isolation or single-patient rooms, with the use of PPE corresponding to airborne infection: gloves, infection-protecting gown, cap and surgical mask and sometimes room-bound shoes [22].

Airborne Precautions (AP)—recommended by CDC [19].

Some citations selected from Siegel et al. 2007; CDC guideline for isolation. Recommendations are in categories where IA is strongest recommendation.

Selected citations: [19] “

1. In acute care hospitals and long-term care settings, place patients who require Airborne Precautions in an AIIR (airborne infection isolate rooms) that has been constructed in accordance with current guidelines. Category IA/IC.

(a) Provide at least six (existing facility) or 12 (new construction/renovation) air changes per hour.

(b) Direct exhaust of air to the outside. If it is not possible to exhaust air from an AIIR directly to the outside, the air may be returned to the air-handling system or adjacent spaces if all air is directed through HEPA filters.

(c) Whenever an AIIR is in use for a patient on Airborne Precautions, monitor air pressure daily with visual indicators (e.g., smoke tubes, flutter strips), regardless of the presence of differential pressure sensing devices (e.g., manometers).

(d) Keep the AIIR door closed when not required for entry and exit.

2. When an AIIR is not available, transfer the patient to a facility that has an available AIIR. Category II.

3. In the event of an outbreak or exposure involving large numbers of patients who require Airborne Precautions:

(a) Consult infection control professionals before patient placement to determine the safety of alternative room that do not meet engineering requirements for an AIIR.

(b) Place together (cohort) patients who are presumed to have the same infection(based on clinical presentation and diagnosis when known) in areas of the facility that are away from other patients, especially patients who are at increased risk for infection (e.g., immune-compromised patients).

(c) Use temporary portable solutions (e.g., exhaust fan) to create a negative pressure environment in the converted area of the facility. Discharge air directly to the outside, away from people and air intakes, or direct all the air through HEPA filters before it is introduced to other air spaces. Category II.

4. Place the patient in an AIIR as soon as possible. If an AIIR is not available, place a surgical mask on the patient and place him/her in an examination room. Once the patient leaves, the room should remain vacant for the appropriate time, generally $1 \mathrm{~h}$, to allow for a full exchange of air. Category IB/IC. 
5. Instruct patients with a known or suspected airborne infection to wear a surgical mask and observe Respiratory Hygiene/Cough Etiquette. Once in an AIIR, the mask may be removed; the mask should remain on if the patient is not in an AIIR. Category IB/IC.

6. Restrict susceptible healthcare personnel from entering the rooms of patients known or suspected to have measles (rubeola), varicella (chickenpox), disseminated zoster, or smallpox if other immune healthcare personnel are available. Category IB.

7. Wear a fit-tested NIOSH-approved N95 or higher level respirator for respiratory protection when entering the room or home of a patient when the following diseases are suspected or confirmed:

(a) Infectious pulmonary or laryngeal tuberculosis or when infectious tuberculosis skin lesions are present and procedures that would aerosolize viable organisms (e.g., irrigation, incision and drainage, whirlpool treatments) are performed. Category IB.

(b) Smallpox (vaccinated and unvaccinated) --- Category II.

(c) No recommendation is made regarding the type of personal protective equipment (i.e., surgical mask or respiratory protection with a N95 or higher respirator) to be worn by susceptible healthcare personnel who must have contact with patients with known or suspected measles, chickenpox or disseminated herpes zoster. Unresolved issue.

8. In acute care hospitals and long-term care and other residential settings, limit transport and movement of patients outside of the room to medically-necessary purposes. Category II.

9. If transport or movement outside an AIIR is necessary, instruct patients to wear a surgical mask, if possible, and observe Respiratory Hygiene/Cough Etiquette. Category II.

10. For patients with skin lesions associated with varicella or smallpox or draining skin lesions caused by $M$. tuberculosis, cover the affected areas to prevent aerosolization or contact with the infectious agent in skin lesions. Category IB.

11. Healthcare personnel transporting patients who are on Airborne Precautions do not need to wear a mask or respirator during transport if the patient is wearing a mask and infectious skin lesions are covered. Category II.

12. Exposure management immunize or provide the appropriate immune globulin to susceptible persons as soon as possible following unprotected contact (i.e., exposed) to a patient with measles, varicella or smallpox: Category IA.

(a) Administer measles vaccine to exposed susceptible persons within $72 \mathrm{~h}$ after the exposure or administer immune globulin within 6 days of the exposure event for high-risk persons in whom vaccine is contraindicated.

(b) Administer varicella vaccine to exposed susceptible persons within $120 \mathrm{~h}$ after the exposure or administer varicella immune globulin (VZIG or alternative product), when available, within $96 \mathrm{~h}$ for high-risk persons in whom vaccine is contraindicated (e.g., immune compromised patients, pregnant women, newborns whose mother's varicella onset was $<5$ days before or within $48 \mathrm{~h}$ after delivery. 
(c) Administer smallpox vaccine to exposed susceptible persons within 4 days after exposure." Citation ended.

"--The environmental recommendations in these guidelines may be applied to patients with other infections that require Airborne Precautions". Selected citation ended.

\subsection{Strict Isolation for High-Risk and Dangerous Pathogens}

Particularly dangerous or unknown infectious agents with high mortality need special treatment in high-risk isolates with separately, controlled ventilation and disinfection of air extraction/waste/water, etc. or in buildings separated from other patients and without common ventilation [22, 30-34].

During the Ebola epidemic from March 2014, health professionals and patients were not protected well enough since the WHO recommended procedures for close contact/droplet infection [120]. The WHO excluded risk of airborne transmission of Ebola, even though it was documented to be transferred via air to primates [120, 121]. The uncertain infection control procedures of WHO were upgraded from September to October 2014 by the WHO and CDC, from contact/droplet infection 1 metre from the patient to strict isolation, but still without measures against airborne infection $[121,122]$. The principle of "prevention is better than cure" was not in use.

The same happened in connection with SARS in 2003 where WHO was recommending a low infection control level, contact/droplets 1 metre from the patient, and had to raise the disease control level up to strict isolation ca. 2 months later on [33].

High-risk infections are recorded almost daily around the world, like the pneumonic plague in Madagascar, outbreaks (partly nosocomial) of multidrug-resistant tuberculosis in all parts of the world and nosocomial outbreaks of Crimean-Congo haemorrhagic fever in Germany after import of ill US soldier from Afghanistan [123-125]. Nearly each day, there are reported new cases of avian influenza, MERS, various haemorrhagic viruses or other dangerous microbes [1, 31-34].

Since 1945, there has been no need for strict isolation in Norway, with the exception of the imported healthcare professionals with Ebola in autumn 2014.

\subsection{Protective Isolation}

Risk of infection may occur when patients with greatly reduced infection defence are coming into contact with infected equipment, textiles or other patients, staff or visitors who have infection or are carriers of possible pathogenic microbes [19, $22,126]$.

The following conditions are particularly vulnerable to contamination, agranulocytosis, neutropenia; $<0.5$ in granulocytes or rapidly decreasing number $<2$, severe burns, patients with severely weakened immune system due to the treatment with immunosuppressive, chemotherapy or radiation (transplants, cancer or leukaemia). 
This heterogeneous group is growing due to a more advanced treatment and more cancer and transplant cases. They should be protected against infection from "outside" by treatment in protective isolation in a clean room with anteroom or sluice and with HEPA-filtered air in a positive pressure room [19, 22, 126-131].

CDC recommends that by allogeneic haematopoietic stem cell transplantation (HSCT), the patients should be treated in protective isolation, especially to protect against fungal infections such as Aspergillus; Category IB. [19]

"As defined by the American Institute of Architecture, air quality for HSCT patients is improved through a combination of environmental controls that include [1] HEPA filtration of incoming air, [2] directed room air flow, [3] positive room air pressure relative to the corridor, [4] well-sealed rooms (including sealed walls, floors, ceilings, windows, electrical outlets) to prevent flow of air from the outside, [5] ventilation to provide $\geq 12$ air changes per hour, [6] strategies to minimize dust (e.g., scrub-able surfaces rather than upholstery and carpet, and routinely cleaning crevices and sprinkler heads), and [7] prohibiting dried and fresh flowers and potted plants in the rooms of HSCT patients. The latter is based on molecular typing studies that have found indistinguishable strains of Aspergillus terreus in patients with haematologic malignancies and in potted plants in the vicinity of the patients" [19].

- In protective isolate should intake air be HEPA filtered which removes $99.97 \%$ of particles larger than or equal $0.3 \mu \mathrm{m}$ in diameter; Category IB. [19]

- The room should be at positive pressure relative to the corridor with a pressure difference of 12.5 pascal or more; Category IB. [19]

- The pressure should be monitored visually every day; Category IA [19].

- The room must be sealed so that no outside air to seep in; Category IB. [19]

- There should be a minimum of 12 air changes per hour; Category IB. [19]

- Use smooth surfaces, avoiding textile furniture and the like, and perform good cleaning; Category II [19].

- Do not use carpeting in corridors or rooms in the area; Category IB. [19]

- The patient should be at least possible out of the room, the necessary examinations, etc., to be implemented in the shortest possible time; Category IB. [19, 22, $126,130,131]$

- If necessary, use respiratory protection if out of isolation; Category II [19, 130].

- Staff are using adequate infection control equipment if the patient has infection; Category IA/IB. [19]

- Patients with respiratory infection —at the same time they need protective isolation-should be transferred to a defined airborne isolate. If HEPA filters are lacking on the air intake to the airborne infection isolation units, a portable system of the HEPA filter may be used in the room to remove fungal spores and bacteria; Category II [19].

Avoid transfers outside the isolate [130, 131]. A retrospective, case-control study of immunocompromised patients in Switzerland showed that when invasive fungal infection occurred, the mortality was over $20 \%$ [131]. An outbreak of fungal infection among 29 patients on a haematological department showed that the more often 
the patient was transferred to other departments/was outside the isolate, the more frequently he was infected with invasive fungi [131]. With more than five patient transfers outside protective isolates, the risk of fungal infection was sixfold higher than if staying in protective isolation. If the patient was transferred during neutropenia, the risk increased by nearly sevenfold [131].

Building activities. Fungal spores are always released during construction activity and may become airborne also in risk areas where severely immunocompromised patients are located [105, 126, 130]. Infectious agents may be spread via air, textiles and equipment with deposition of fungal spores and other microbes during the construction period. Fungal spores follow air currents far away [105]. Construction activity must therefore be coordinated with appropriate departments and wards so that the patient area is shielded. Air from construction places should not leak into patient areas and be taken out directly from the building in such a way that it does not re-enter through the systems for intake of air.

Leakage of water in buildings. Fungal growth in patient room walls is due to neglected maintenance of buildings for many years and usually comes from water leakage from the old pipes, roof leaks or poorly maintained bathrooms. Patients should not stay in rooms with suspected fungal growth and decay!

Control of fungi should be implemented in protective isolates and storages for such isolates once a year or more frequently when suspected water leaks and rot. The requirement is 0 fungal spores per 1000 litres of air using the SAS-slit sampler.

Patients must be protected against infections during care and treatment [19, 22, 132-134].

Cleaning and disinfection of rooms, surfaces and equipment between infection susceptible patients must be extra careful since many - at the same time-have serious infections, including resistant bacteria. Despite a good cleaning, abundant amounts of microbes may be detected in the environment and the equipment after cleaning $[135,136]$.

\subsection{Protecting Staff Against Serious Infection}

Healthcare professionals who treat infectious patients may be highly exposed to infection, although they really should be protected [3, 6-8, 19, 22, 137, 138].

At the beginning of the SARS epidemic in 2003, $90 \%$ of SARS patients were the hospital personnel who had taken care of the first SARS patients [33]. During the Ebola outbreak in 2014, healthcare workers were again severely attacked by the disease and death in the first phase, until a more protective personal protective equipment system was in place [34, 120-122]. There is still a great variety in international guidelines in terms of personal protection equipment (PPE) by Ebola virus for healthcare workers [121]. The WHO, United Kingdom and CDC defined Ebola as non-airborne infection in 2014 and still does the same in 2017 [121]. None of these recommended respiratory protection for suspected Ebola infection in AugustSeptember 2014, at least half a year after the start of the epidemic. Only the United Kingdom recommended respirator mask for confirmed Ebola. There was no covering of the head or neck, not either during aerosol-generating procedures! 
In October 2014, the CDC upgraded the PPE measures to strict isolation measures for proven Ebola infection, while the earlier PPE measures were recommended for suspected Ebola infection (Table 21.1) [120-122].

Table 21.1 Recommend use of infection control equipment; PPE (personal protective equipment) in Ebola virus guidelines from the World Health Organization (WHO), United Kingdom (UK) and the Centers for Disease Control and Prevention (CDC), USA (Source: Andersen BM Hospital Healthcare 2015; March [121])

Comparing the recommended PPE equipment by Ebola infection in guidelines from the WHO, United Kingdom and CDC in 2014 [120-122]

\begin{tabular}{|c|c|c|c|c|}
\hline & $\begin{array}{l}\text { WHO } \\
2014^{a}\end{array}$ & UK $2014^{\mathrm{b}}$ & $\begin{array}{l}\text { CDC } \\
2014^{c}\end{array}$ & $\begin{array}{l}\text { CDC } \\
2014^{d}\end{array}$ \\
\hline & September & September & August & $\begin{array}{l}\text { October } \\
20\end{array}$ \\
\hline \multicolumn{5}{|l|}{ Spread of Ebola infection } \\
\hline Direct contact? & Yes & Yes & Yes & Yes \\
\hline Indirect contact? & $?$ & Yes & Yes & Yes \\
\hline Airborne infection? & No & No & No & No \\
\hline \multicolumn{5}{|l|}{ The use of PPE by: } \\
\hline \multicolumn{5}{|l|}{ Suspected cases of Ebola } \\
\hline Eye protection? & Yes & Yes & Yes & \\
\hline Gown? & Yes & $\begin{array}{l}\text { Plastic } \\
\text { apron }\end{array}$ & Yes & \\
\hline Gloves? & Yes & Yes & Yes & \\
\hline Face masks/surgical masks & Yes & Yes & Yes & \\
\hline Respirators/N95/P3 mask, etc. & No & No & No & \\
\hline Hair/head/neck protection? & No & No & No & \\
\hline Specific shoes/shoe covers? & Yes & No & No & \\
\hline \multicolumn{5}{|l|}{ Confirmed cases of Ebola } \\
\hline Eye protection? & Yes & Yes & Yes & Yes \\
\hline Gown? & Yes & Yes & Yes & Yes \\
\hline Gloves? & Yes & Yes & Yes & Yes \\
\hline Face masks/surgical masks & Yes & No & Yes & No \\
\hline Respirators/N95/P3 mask, etc. & No & Yes & No & Yes \\
\hline Hair/head/neck protection? & No & No & No & Yes \\
\hline Specific shoes/shoe covers? & Yes & No & No & Yes \\
\hline \multicolumn{5}{|l|}{ Aerosol-generating procedures } \\
\hline Respirators/N95/P3 mask, etc. & Yes & Yes & Yes & Yes \\
\hline Hair/head/neck protection? & No & No & No & Yes \\
\hline Specific shoes/shoe covers? & Yes & No & Yes & Yes \\
\hline
\end{tabular}

${ }^{a}$ WHO. Interim infection prevention and control guidance for care of patients with suspected or confirmed filovirus haemorrhagic fever in healthcare settings, with focus on Ebola. September 2014

bUK, the Department of Health. Management of hazard group 4 viral haemorrhagic fevers and similar human infectious diseases of high consequences. September 2014

${ }^{\mathrm{c}} \mathrm{CDC}$. Infection prevention and control recommendations for hospitalized patients with known or suspected Ebola haemorrhagic fever in US hospitals. August 2014

${ }^{\mathrm{d}} \mathrm{CDC}$. Guidance on personal protective equipment to be used by healthcare workers during management of patients with Ebola virus disease in US hospitals, including procedures for putting on (donning) and removing (doffing). October 20, 2014 
During the pandemic flu in 2009, Norwegian health authorities did not allow the staff at hospitals to use respirator masks (P3 masks) when taking care of the flu patients; they should use surgical masks [138]. Exceptions were for aerosol-generating procedures. The same health authorities went public and said that surgical masks did not have any protective effect! [138]

Recurrent problems are that the health authorities are not able to see the importance in protecting health professionals who are-and will always be - the frontline workers, even at the most serious infectious diseases [137]. Governments that are not willing to take care of their healthcare employees create unnecessary fear and reluctance to make a good contribution during outbreaks. If the disease is not as dangerous as SARS and Ebola, a highly contagious pandemic influenza or a large norovirus outbreak could paralyse the healthcare system when a high number of the staff get sick at the same time. By preventing disease transmission to health professionals, the hospital can be operatively enough to handle properly other serious diseases such as traffic accidents, myocardial infarction, stroke, etc., even at largescale epidemics.

In spite of problems concerning isolation and prevention of spread of emerging and new serious infections, new guidelines are now appearing, which works with reduction of infection control in severely affected countries with endemic infections $[139,140]$.

\subsection{CDC Isolation Guidelines - Overview - Selected by the Author}

\begin{tabular}{|c|c|c|}
\hline \multicolumn{3}{|c|}{$\begin{array}{l}\text { Administrative responsibilities: The hospital management should ensure implementation of the } \\
\text { following recommendations }\end{array}$} \\
\hline & Isolation guidelines - selected from CDC & \\
\hline & Measures & Category \\
\hline 1 & $\begin{array}{l}\text { Include infection prevention measures in the safety program for } \\
\text { patients and the working environment }\end{array}$ & $\mathrm{IB} / \mathrm{IC}$ \\
\hline \multirow[t]{2}{*}{2} & Preventing the spread of infection-a priority for the hospital & \\
\hline & $\begin{array}{l}\text { Administrative support, resources for maintenance of the } \\
\text { infection control program }\end{array}$ & IB/IC \\
\hline \multirow[t]{2}{*}{3} & $\begin{array}{l}\text { Securing enough qualified infection control personnel to } \\
\text { operate and be responsible for the hospital }\end{array}$ & \\
\hline & Infection control program & IB/IC \\
\hline 4 & Include infection control in daily treatment and care of patients & IB \\
\hline \multirow[t]{2}{*}{5} & $\begin{array}{l}\text { Delegate responsibility for infection control personnel for } \\
\text { disease control as where positioning the patient with }\end{array}$ & \\
\hline & $\begin{array}{l}\text { Infected patients and the transport and transfer of patients with } \\
\text { infection }\end{array}$ & IC \\
\hline \multirow[t]{2}{*}{6} & $\begin{array}{l}\text { Involve infection control personnel in the building, construction } \\
\text { and design, insulation capacity, }\end{array}$ & \\
\hline & $\begin{array}{l}\text { Airborne isolate protective insulation and ventilation } \\
\text { conditions, air changes, etc. }\end{array}$ & IB/IC \\
\hline
\end{tabular}


Administrative responsibilities: The hospital management should ensure implementation of the following recommendations

\begin{tabular}{|c|c|c|}
\hline \multirow[t]{3}{*}{7} & $\begin{array}{l}\text { Secure laboratory support-microbiology to contact tracing, } \\
\text { documentation of disease transmission }\end{array}$ & \\
\hline & $\begin{array}{l}\text { Between patients, surveillance cultures, rapid testing, reports of } \\
\text { antibiotic sensitivity, }\end{array}$ & \\
\hline & Molecular typing by outbreaks, etc. & IB \\
\hline \multirow[t]{2}{*}{8} & $\begin{array}{l}\text { Resources for the follow-up of health professionals with regard } \\
\text { to vaccine and post-exposure }\end{array}$ & \\
\hline & $\begin{array}{l}\text { Organization of treatment personnel with infections/infectious } \\
\text { carriers, etc. }\end{array}$ & $\mathrm{IB} / \mathrm{IC}$ \\
\hline \multirow[t]{2}{*}{9} & $\begin{array}{l}\text { All places that deliver health services should have enough } \\
\text { infection control resources, hand hygiene agents, }\end{array}$ & \\
\hline & PPE, gloves, coat and face and eye protection & $\mathrm{IB} / \mathrm{IC}$ \\
\hline 10 & $\begin{array}{l}\text { Multipurpose articles to be properly cleaned and disinfected } \\
\text { prior to use on a new patient }\end{array}$ & IA/IC \\
\hline 11 & $\begin{array}{l}\text { Establish systems for early detection of infection and location } \\
\text { of patients with infection }\end{array}$ & IB \\
\hline \multirow[t]{2}{*}{12} & $\begin{array}{l}\text { Establish procedures to limit infectious visitors, especially this } \\
\text { should be investigated }\end{array}$ & \\
\hline & $\begin{array}{l}\text { For visitors to patients with severe renal infection of defence- } \\
\text { High-risk patients }\end{array}$ & IB \\
\hline \multicolumn{2}{|c|}{$\begin{array}{l}\text { Siegel a } 2007 \text { guideline for isolation. Recommendations in categories where IA is } \\
\text { strongest recommendation [19] }\end{array}$} & \\
\hline
\end{tabular}

Contact infection prevention. Selected from the CDC guideline 2007

\begin{tabular}{|c|c|c|}
\hline & Measures & Category \\
\hline 1 & $\begin{array}{l}\text { Place the patient in a single room or cohort of another patient with the same } \\
\text { pathogen }\end{array}$ & IB \\
\hline 2 & $\begin{array}{l}\text { Gloves when handling the patient, equipment and rooms. Put on gloves before } \\
\text { going into the room }\end{array}$ & IB \\
\hline 3 & $\begin{array}{l}\text { Infection gown when handling the patient, equipment and room. Put on before } \\
\text { going into the room }\end{array}$ & IB \\
\hline 4 & $\begin{array}{l}\text { Remove infection gown and gloves and perform hand hygiene before leaving } \\
\text { the area }\end{array}$ & IB \\
\hline 5 & Limit patient transport outside the isolation ward & II \\
\hline 6 & $\begin{array}{l}\text { If necessary, patient transport in clean bed with clean equipment and covered } \\
\text { with clean cloth }\end{array}$ & II \\
\hline 7 & $\begin{array}{l}\text { Do not transport the patient with applied infection control equipment (PPE); } \\
\text { wash your hands before transport }\end{array}$ & II \\
\hline 8 & $\begin{array}{l}\text { Wear clean PPE for processing and handling of the patient where this is } \\
\text { obtained (X-ray, etc.) }\end{array}$ & II \\
\hline \multirow[t]{2}{*}{9} & $\begin{array}{l}\text { Use the most disposables. Reusable equipment must be disinfected before the } \\
\text { next use }\end{array}$ & IB \\
\hline & $\begin{array}{l}\text { Siegel a } 2007 \text { guideline for isolation [19]. Recommendations in categories } \\
\text { where IA is strongest recommendation }\end{array}$ & \\
\hline
\end{tabular}


Airborne infection-prevention-selected from the CDC guideline 2007

\begin{tabular}{|c|c|c|}
\hline & Measures & Category \\
\hline 1 & $\begin{array}{l}\text { Place the patient with defined or suspected airborne infection in airborne } \\
\text { isolate }\end{array}$ & $\mathrm{IA} / \mathrm{IC}$ \\
\hline 2 & At least six (lower) or 12 (new) air changes per hour & IA/IC \\
\hline 3 & Vent be directly optionally HEPA-filtered air & $\mathrm{IA} / \mathrm{IC}$ \\
\hline 4 & $\begin{array}{l}\text { Daily monitoring of the under pressure in airborne infection isolation units, } \\
\text { several ways, keep doors closed }\end{array}$ & IA/IC \\
\hline 5 & $\begin{array}{l}\text { Lacking airborne infection isolation-transferable to another hospital with } \\
\text { airborne infection isolation (especially tbc) }\end{array}$ & II \\
\hline 6 & Cohort of patients with the same proven infection is possible & II \\
\hline 7 & $\begin{array}{l}\text { Restriction for personnel who are not immune (measles, etc.) or vaccinated } \\
\text { against agent (BCG) }\end{array}$ & IB \\
\hline 8 & Respirators/respirator N-95 with fitting test used for guidelines, or a gag & IB \\
\hline \multirow[t]{2}{*}{9} & Current vaccines or immunoglobulin to exposed non-immune, quickly & IA \\
\hline & $\begin{array}{l}\text { Siegel a } 2007 \text { guideline for isolation. Recommendations in categories where IA } \\
\text { is strongest recommendation [19] }\end{array}$ & \\
\hline
\end{tabular}

\section{References}

1. Andersen BM. Handbook of hygiene and infection control in hospitals. Part 1 microbiology and infection control. Bergen: Fagbokforlaget; 2014.

2. Infectious Disease Act. Law 5 August 1994 no. 55 of protection against infectious diseases.

3. Regulations in infection control in health facilities - hospital infections, established by the Health and Social Affairs July 5, 1996 and July 17, 2005 pursuant to § 4-7 and § 7-11 of the Act on Aug. 5, 1994 no. 55 of protection against infectious diseases.

4. Action plan for infection control in Norwegian hospitals. Health Directorate's Guidance series 2-92. Directorate of Health.

5. Use of isolation to prevent spread of infection in hospitals. Health Directorate's Guidance series: Directorate of Health, Oslo. 1988: p. 2-88.

6. Health Personnel Act. Department of Health and Social Affairs. Act 1999-07-02 No. 64: 2001.

7. Regulations for protection against exposure to biological agents (bacteria, viruses, fungi, etc.) in the workplace. Directorate of Labour Inspection. December 19, 1997.

8. European Parliament and Council Directive 2000/54/EC of 18 September 2000 on the protection of workers from the risks related to exposure to biological agents at work.

9. CDC Draft Guideline for Isolation Precautions in Hospital. Fed Regist. 1994;59:55552-70. and 2004

10. Garner JS. Guideline for isolation precautions in hospitals. Infect Control Hosp Epidemiol. 1996;17:53-80.

11. Edmond M. Isolation. Infect Control Hosp Epidemiol. 1997;18:58-64.

12. CDC Draft Guideline for Preventing the transmission of Mycobacterium tuberculosis in health care facilities. Fed Regist. 1994;59:54242-303. and 2004; 69: 33034

13. Barlow G, Sachdev N, Nathwani D. The use of adult isolation facilities in a UK infectious disease unit. J Hosp Infect. 2002;50:127-32.

14. Damji S, Barlow GD, Patterson L, Nathwani D. An audit of the use of isolation facilities in a UK National Health Service trust. J Hosp Infect. 2005;60:213-7.

15. Falagas ME, Kopterides P. Risk factors for the isolation of multi-drug-resistant Acinetobacter baumannii and Pseudomonas aeruginosa: a systematic review of the literature. J Hosp Infect. 2006;64:7-15. 
16. Hansen S, Stamm-Balderjahn S, Zuschneid I, et al. Closure of medical departments during nosocomial outbreak: data from systematic analysis of the literature. J Hosp Infect. 2007;65:348-53.

17. CDC. Management of multidrug-resistant organisms in healthcare settings, 2006. CDC. 2006: 1-72.

18. CDC. Prevention of transmission of multidrug resistant organisms 2009. In: CDC; 2009.

19. Siegel JD, Rhinehart E, Jackson M et al. 2007 guideline for isolation precautions: preventing transmission of infectious agents in healthcare settings. CDC. 2007.

20. Calfee DP, Salgado CD, Milstone AM, et al. Strategies to prevent methicillin-resistant Staphylococcus aureus transmission and infection in acute care hospitals: 2014 update. Infect Control Hosp Epidemiol. 2014;35:772-96.

21. Pallin DJ, Camargo CA, Yoke DS, Schuur JD. Variability of contact precaution policies in US Emergency Departments. Infect Control Hosp Epidemiol. 2014;35:310-2.

22. Andersen BM. Isolation. In: Handbook of hygiene and infection control in hospitals. Oslo: Ullevål University Hospital; 2008. p. 216-48.

23. Andersen BM, Seljordslia B, Hochlin K, Rasch M, Syversen G. A predicted outbreak in an overcrowded, administratively neglected and run-down haemodialysis unit as an offer of "new public management" in Norwegian hospitals. J Hosp Admin. 2013;2:01.10.

24. Andersen BM, Lindemann R, Bergh K, Nesheim BI, Syversen G, Solheim N, Laugerud F. Spread of methicillin-resistant Staphylococcus aureus in a neonatal intensive unit associated with understaffing, overcrowding and mixing of patients. J Hosp Infect. 2002;(1):1-7.

25. Marier RL. The design of isolation rooms. Infect Control Hosp Epidemiol. 1996;17:3-4.

26. Walker JT, Hoffman P, Bennett AM, Vos MC, Thomas M, Tomlinson N. Hospital and community acquired infection and the built environment- design and testing of infection control rooms. J Hosp Infect. 2007;65:43-9.

27. Eveillard M, Tramier B, Schmit JL, Lescure FX, Biendo M, Canarelli B, et al. Evaluation of the contribution of isolation precautions in prevention and control of multi-resistant bacteria in a teaching hospital. J Hosp Infect. 2001;47:116-24.

28. Andersen BM, Ringertz SH, Gullord TP, Hermansen W, Lelek M, Norman BI, Tilrem Nystad M, Anderson Rød K, Røed RT, Smidesang IJ, Solheim N, Tandberg S, Halsnes R, Høystad MW. A three-year survey of nosocomial and community- acquired infections, antibiotic treatment and re-hospitalization in a Norwegian health region. J Hosp Infect. 2000;44:214-23.

29. Andersen BM, Rasch M, Hochlin K, Tollefsen T, Sandvik L. Hospital-acquired infections before and after healthcare reorganization in a tertiary University Hospital in Norway. J Public Health. 2009;7:1-7.

30. Andersen BM, Hochlin K, Lereim I. Isolation of dangerous infections. In: Handbook of hygiene and infection control in hospitals. Oslo: Ullevål University Hospital; 2008. p. 563-6.

31. Andersen BM. Scenario pandemic influenza and pandemic fulgeinfluensa. In: Handbook of hygiene and infection control in hospitals. Part 1 microbiology and infection control. Bergen: Fagbokforlaget; 2014. p. 310-8.

32. Andersen BM. Avian influenza with pandemic potential. In: Handbook of hygiene and infection control in hospitals. Part 1 microbiology and infection control. Bergen: Fagbokforlaget; 2014. p. 300-9.

33. Andersen BM. SARS and MERS - dangerous coronavirus. In: Handbook of hygiene and infection control in hospitals. Part 1 microbiology and infection control. Bergen: Fagbokforlaget; 2014. p. 319-46.

34. Andersen BM. Ebola-, Lassa-, and other hemorrhagic viruses. In: Handbook of hygiene and infection control in hospitals. Part 1 microbiology and infection control. Fagbokforlaget Bergen 2014: 291-299.

35. Andersen BM. Hospital infections at Ullevål hospital. Occurrence and additional expenses. Tidsskr Nor Legeforen. 1996;116:2903 to 2907.

36. Andersen BM, Bergh K, Steinbakk M, Syversen G, Magnæs B, Dalen H, Bruun JN. A Norwegian nosocomial outbreak of methicillin-resistant Staphylococcus aureus resis- 
tant to fusidic acid and susceptible two other anti-staphylococcal agents. J Hosp Infect. 1999;41:123-32.

37. Grub C, Holberg Petersen M, Medbøe S, Andersen BM, Syversen G, Melby KK. A multidrug resistant, methicillin-susceptible strain of Staphylococcus aureus from a neonatal intensive care unit in Oslo, Norway. Scand J Infect Dis. 2010;42:148-51.

38. Rees J, Davies HR, Birchall C, Price J. Psychological effects of source isolation nursing (2) patient satisfactory. Nurs Stand. 2000;14:275-80.

39. Day HR, Preencevich EN, Harris AD, et al. Depression, anxiety, and moods of hospitalized patients under contact precaution. Infect Control Hosp Epidemiol. 2013;34:251-8.

40. Cohen E, Austin J, Weinstein M, Matlow A, Redelmeier DA. Care of children isolated for infection control: a prospective observational cohort study. Pediatrics. 2008;122:411-5.

41. Morgan DJ, Diekema DJ, Sepkowitz K, Perencevich EN. Adverse outcomes associated with contactless precautions: a review of the literature. Am J Infect Control. 2009;37:85-93.

42. Gasink LB, Singer K, Fishman GB, et al. Contact isolation for infection control in hospitalized patients: is patients satisfaction affected? Infect Control Hosp Epidemiol. 2008;29:275-8.

43. Abad C, Fearday A, Safdar N. Adverse effects of isolation in hospitalized patients: a systematic review. J Hosp Infect. 2010;76:97-102.

44. Tang JW, Eames In Li Y, et al. Door-opening motion can potentially lead to a transient breakdown in negative-pressure isolation conditions: the importance of vorticity and buoyancy airflows. J Hosp Infect. 2005;61:283-6.

45. Tognotti E. Lessons from the history of quarantine, from plague to influenza a. Emerg Infect Dis. 2013;19:254-7.

46. Schiøtz C. Textbook of hygiene. Oslo: Fabritius \& Sønners Forlag; 1937.

47. Bourouiba L, Dehandschoewerker E, Bush JWM. Violent expiratory events: on coughing and sneezing. J Fluid Mech. 2014;845:537-63.

48. NORM/NORM-VET 2013. Usage of antimicrobial agents and occurrence of antimicrobial resistance in Norway. Troms $\varnothing / O s l o ; 2014$.

49. Olafsen K, Hotvedt R, Andersen BM, Almdahl SM, Sorlie D. Nosocomial infection with resistant Enterobacter cloacae. Tidsskr Nor Legeforen. 1989;109:332-6.

50. Bukholm G, Tannæs T, Kjelsberg ABB, Smith-Erichsen N. An outbreak of multidrug-resistant Pseudomonas aeruginosa associated with increased risk of patient death in an intensive care unit. Infect Control Hosp Epidemiol. 2002;23:441-6.

51. Andersen BM. Food contamination is a neglected problem. Aftenposten Viten 28.10.2014.

52. Best EL, Fawlewy WN, Parnell P, Wilcox MH. The potential for airborne dispersal of Clostridium difficile from symptomatic patients. Clin Infect Dis. 2010;50:1450-7.

53. Lessa FC, Mu Y, Bamberg WM, et al. Burden of Clostridium difficile infection in the United States. N Engl J Med. 2015;372:825-34.

54. Pro-Med-mail, on March 1, 2015. Measles update.

55. Andersen BM. Outbreaks of acute gastroenteritis in and outside the Ullevål Hospital in December 1994-February 1995. MSIS epiuke 8, 1995.

56. Andersen BM Størvold G, Vainio K. Norovirus gastro-enteritis at Ullevål University. Tidsskr Nor Legeforen. 2003;123:1239.

57. Halwani M, Solaymani-Dodaran M, Grundmann H, Coupland C, Slack R. Cross-transmission of nosocomial pathogens in an adult intensive care unit: incidence and risk factors. J Hosp Infect. 2006;63:39-46.

58. Andersen BM. Virus associated with skin rash and children's diseases. In: Handbook of hygiene and infection control in hospitals. Part 1 microbiology and infection control. Bergen: Fagbokforlaget; 2014. p. 256-67.

59. Andersen BM. Bordetella pertussis - whooping cough. In: Handbook of hygiene and infection control in hospitals. Part 1 microbiology and infection control. Bergen: Fagbokforlaget; 2014. p. 120. 
60. Hafstad A, Skogstrøm L. Healthcare professional arguments and sick people die. Aftenposten August 5, 2002.

61. Fusco FM, Puro V, Baka A, et al. Isolation rooms for highly infectious diseases: an inventory of capabilities in European countries. J Hosp Infect. 2009;73:15-23.

62. Marklund LA. Patient care in a biological safety level 4 (BSL-4) environment. Crit Care Nurs Clin North Am. 2003;15:245-55.

63. Zimring C, Denham ME, Jacob JT, et al. Evidence-based design of health care facilities: opportunities for research and practice in infection prevention. Infect Control Hosp Epidemiol. 2013;

64. Zimring C, Jacob JT, Denham ME, et al. The role of facility design in preventing the transmission of healthcare-associated infections: background and conceptual framework. Health Environ Res Design J. 2013;7:18-30.

65. Jacob TJ, Kasali A, Steinberg JP, Zimring C, Denham ME. The role of the hospital environment in preventing healthcare-associated infections caused by pathogens transmitted through the air. Health Environ Res Design J. 2013;7:74-98.

66. Steinberg JP, Denham ME, Zimring C, Kasali A, Hall KK, Jacob JT. The role of the hospital environment in the prevention of healthcare-associated infections by contact transmission. Health Environ Res Design J. 2013;7:46-73.

67. Stumpfs DJ, DeSouza SBC, Konkewicz LR, da Silva CF, Macedo ABT, dos Santos RP. The impact of a single ward for cohorting patients with infection due two multidrug-resistant organisms. Infect Control Hosp Epidemiol. 2013;34:864-5.

68. Kvittingen J, Trymer A. Hospital endemic with methicillin-resistant staphylococci. Tidsskr Nor Legeforen. 1977;97:813-6.

69. Boone SA, Gerba CP. Significances of fomites in the spread of respiratory and enteric viral disease. Appl Environ Microbiol. 2007;73:1687-96.

70. Freeman JT, Nimmo J, Gregory E, et al. Predictors of hospital surface contamination with extended-spectrum beta-lactamase-producing Escherichia coli and Klebsiella pneumoniae: patient and organisms factors. Antimicrob Res Infect Control. 2014;3:5.

71. Sui W, Wang J, Wang H, et al. Comparing the transmission potential of methicillin-resistant Staphylococcus aureus and multidrug-resistant Acinetobacter baumannii among inpatients overusing target environmental monitoring. Am J Infect Control. 2013;41:411-5.

72. Weber DJ, Rutala WA, Miller MB, Huslage K, Sickbert-Bennett E. Role of hospital surfaces in the transmission of emerging healthcare-associated pathogens: norovirus, Clostridium difficile, and Acinetobacter species. Am J Infect Control. 2010;38:25-33.

73. Dancer SJ. Mopping up hospital infection. J Hosp Infect. 1999;43:85-100.

74. Andersen BM, Rasch M, Hochlin K, et al. Decontamination of rooms, medical equipment and ambulances, overusing a dry mist of hydrogen peroxide disinfectant. J Hosp Infect. 2006;62:149-55.

75. Andersen BM, Hochlin K, Daling JP. Cleaning and decontamination of reusable medical equipment, including the use of hydrogen peroxide dry-mist gas decontamination. J Microbial Biochem Technol. 2012;4:3-10.

76. Andersen BM, Syversen G, Thoresen H, Rasch M, Hochlin K, Seljordslia B, Snevold I, Berg E. Failure of dry mist of hydrogen peroxide 5\% to kill Mycobacterium tuberculosis. J Hosp Infect. 2010;76:80-3.

77. Festini F Buzzetti R, Bassi C, et al. Isolation measures for prevention of infection with respiratory pathogens in cystitis fibrosis: a systematic review. J Hosp Infect. 2006;64:1-6.

78. Gandra S, Barysauskas CM, Mack DA, Barton B, Finberg R, Ellison RT III. Impact of contact precautions on falls, pressure ulcers and transmission of MRSA and VRE in hospitalized patients. J Hosp Infect. 2014;88:170-6.

79. Andersen BM. Economic consequences of hospital infections in a 1000 bed University Hospital in Norway. Infect Control Hosp Epidemiol. 1998;19:805-7.

80. Andersen BM, Tollefsen T, Seljordslia B, Hochlin K, Syversen G, Jonassen AZ, Rasch M. Rapid MRSA test in exposed persons: costs and savings in hospitals. J Infect. 2010;60:293-9. 
81. Teltscher DT, Hanley J, Loo V. Infection acquisition following intensive care unit room privatization. Arch Intern Med. 2011;171:32-8.

82. Manian FA, Ponzillo JJ. Compliance with routine use of gowns by healthcare workers (HCW) and non-HCW visitors on entry into the rooms of patients under contact precautions. Infect Control Hosp Epidemiol. 2007;28:337-40.

83. Pettinger A, Nettleman MD. Epidemiology of isolation precautions. Infect Control Hosp Epidemiol. 1991;12:303-7.

84. Morgan DJ, Pinel L, Shardell M, et al. The effect of contact precautions on healthcare worker activity in acute care hospitals. Infect Control Hosp Epidemiol. 2013;34:69-73.

85. Andersen BM. Staphylococcus aureus. In: Bacteria and disease. Epidemiology, infections and infection control. Oslo: Gyldendal Norsk Forlag; 2005. p. 110-42.

86. Guideline for hand washing in healthcare settings. MMWR. 2002;51:1-45.

87. Ransjø U, Lytsy B, Melhus $\AA$, et al. Hospital outbreak control requires joint efforts from hospital management, microbiology and infection control. J Hosp Infect. 2010;76:26-31.

88. Caffrey AR, LaPlante KL. Changing epidemiology of methicillin-resistant Staphylococcus aureus in the veterans affairs healthcare system, 2002-2009. Infection. 2012;40:291-7.

89. Rusin P, Maxwell S, Gerba C. Comparative surface -to-hand and fingertip-to-mouth transfer efficiency of gram-positive bacteria, gram-negative bacteria, and phage. J Appl Microbiol. 2002;93:585-92.

90. Ludlam HA, Swayne RL, Kearns AM, et al. Evidence from a UK teaching hospital that MRSA is primarily transmitted by the hands of healthcare workers. J Hosp Infect. 2010;74:296-9.

91. Albrich WC, Harbarth S. Health-care workers: source, vector or victim of MRSA? Lancet Infect Dis. 2008;8:289-301.

92. McGuckin M, Govednik J. Patient empowerment and hand washing, 1997-2012. J Hosp Infect. 2013;84:191-9.

93. Kundrapu S, Sunkesula V, Jury Ideshpande A, Donskey CJ. A randomized trial of soap and water hand wash versus alcohol hand rub for removal of Clostridium difficile spores from hands of patients. Infect Control Hosp Epidemiol. 2014;35:204-6.

94. Banfield KR, Kerr KG. Could hospital patients' hands constitute a missing link? J Hosp Infect. 2005;61:183-8.

95. Landers T, Abusalem S, Coty MB, Bingham J. Patient-centred hand washing: the next step in infection prevention. Am J Infect Control. 2012;40:S11-7.

96. Gagne D, Bedard G Maziade PJ. Systematic Patients' hand disinfection: impact on methicillin-resistant Staphylococcus aureus infection rates in a community hospital. J Hosp Infect. 2010;75:269-72.

97. Chang S, Sethi AK, Stiefel U, Cadnum JL, Donskey CJ. Occurrence of skin and environmental contamination with methicillin-resistant Staphylococcus aureus before results of polymerase chain reaction at hospital admission become available. Infect Control Hosp Epidemiol. 2010;31:607-12.

98. Skally M, Duffy F, Burns K, et al. What may be lurking in the hospital undergrowth? Inapparent cross-transmission of extended-spectrum beta-lactamase-producing Klebsiella pneumoniae. J Hosp Infect. 2014;88:156-61.

99. Hamel M, Zoutman D, O'Callaghan C. The exposure to hospital roommates as a risk factor for healthcare-associated infection. Am J Infect Control. 2010;38:173-81.

100. Shiomori T, Miyamoto H, Makishima F, Yoshida M, Fujiyoshi T, Udaka T, et al. Evaluation of bedmaking-related airborne and surface methicillin-resistant Staphylococcus aureus contamination. J Hosp Infect. 2002;50:30-5.

101. Andersen BM, Solheim N, Kruger E, Sogn K, Moløkken I, Levy F. Effect of floor cleaning bacteria and organic materials in patient. Tidsskr Nor Legeforen. 1997;117:838-41.

102. Andersen BM, Rasch M, Kvist J, Tollefsen T, Lukkassen R, Sandvik L, Welo A. Floor cleaning: effect on bacteria and organic materials in hospital rooms. J Hosp Infect. 2009;71:57-65.

103. Andersen BM, Røed RTH, Solheim N, Levy F, Bratteberg A, Kristoffersen K, Moløkken I. Air quality and microbiological contamination in operating theaters with and without laminar air flow. Tidsskr Nor Legeforen. 1998;20:3148-51. 
104. Andersen BM, Solheim N. Occlusive scrub suits in operating theaters during cataract surgery; effect on airborne contamination. Infect Control Hosp Epidemiol. 2002;23:218-20.

105. Balm MND, Jure R, Teo C, et al. Hot and steamy: outbreak of Bacillus cereus in Singapore associated with construction work and laundry practices. J Hosp Infect. 2012;81:224-30.

106. Beggs CB. The airborne transmission of infection in hospital buildings: fact or fiction? Indoor Built Environ. 2003;12:1-10.

107. Li Y, Leung GM, Tang JW, et al. Role of ventilation in airborne transmission of infectious agents in the built environment- a multi-disiplinary systematic review. Indoor Air. 2007;17:2-18.

108. Kao PH, Yang RJ. Virus diffusion in isolation rooms. J Hosp Infect. 2006;62:338-45.

109. Moser MR, Bender TR, Margolis HS, Noble GR, Kendal AP, Ritter DG. An outbreak of influenza abroad a commercial airliner. Am J Epidemiol. 1979;110:1-6.

110. Tellier R. Review of aerosol transmission of influenza A virus. Emerg Infect Dis. 2006;12:1657-62.

111. Aintablian N, Walpita P, Sawyer MH. Detection of Bordetella pertussis and respiratory syncytial virus in air samples from hospital rooms. Infect Control Hosp Epidemiol. 1998;19:918-23.

112. Bischoff WE, Bassetti S, Bassetti-Wyss BA, Wallis ML, et al. Airborne dispersal as a novel transmission route of coagulase-negative staphylococci, interaction between coagulase-negative staphylococci and rhinovirus infection. Infect Control Hosp Epidemiol. 2004;25:504-11.

113. Gehanno JF, Louvel A, Nouvellon M, Caillard JF, Pestel-Caron M. Aerial dispersal of methicillin-resistant Staphylococcus aureus in hospital rooms by infected and colonised patients. J Hosp Infect. 2009;71:256-62.

114. Creamer E, Shore AC, Deasy EC, et al. Air and surface contamination patterns of methicillinresistant Staphylococcus aureus on eight acute hospital wards. J Hosp Infect. 2014;86:201-8.

115. Bernard MC, Lanotte P, Lawrence C, Goudeau A, Bernard L. Air contamination around patients colonized with multidrug-resistant organisms. Infect Control Hosp Epidemiol. 2012;33:949-51.

116. Derrick JL, Li PTY, Tang SPY, Gomersall CD. Protecting staff against airborne viral particles: in vivo efficiency of laser masks. J Hosp Infect. 2006;64:278-81.

117. Mulin B, Rouget $\mathrm{C}$, Clement $\mathrm{C}$, et al. Association of private isolation rooms with ventilator-associated Acinetobacter baumannii pneumonia in surgical intensive-care unit. Infect Control Hosp Epidemiol. 1997;18:499-503.

118. Morawska L. Droplet fate in indoor environments, or can we prevent the spread of infection? Proceedings: Indoor Air. 2005: P9-23.

119. Carducci A, Verani M, Lombardi R, Casini B, Privitera G. Environmental survey to assess viral contamination of air and surfaces in hospital settings. J Hosp Infect. 2011;77:242-7.

120. Andersen BM. Infection control is not working. Promed-mail on Sept. 14, 2014.

121. Andersen BM. International infection control guidelines may not protect against Ebola. Hospital Health Care. 2015; March.

122. Andersen BM. WHO, CDC, and the UK - Guidelines does not protect against Ebola. BIT's 5th Annual Wold Congress of Microbes - 2015 (WCM 2015), July 31-August 2, 2015 Shanghai China.

123. Richard V, Riehm JM, Herindrainy P, et al. Pneumonic plague outbreak, Northern Madagascar 2011. Emerg Infect Dis. 2015;21:8-15.

124. Chee CBE, Gan SH, Ong RT, et al. Multi drug-resistant tuberculosis outbreak in gaming centres, Singapore, 2012. Emerg Infect Dis. 2015;21:179-80.

125. Conger NG, Paolino KM, Osborne EC, et al. Health care response to CCHF in US soldier and nosocomial transmission to health care providers, Germany, 2009. Emerg Infect Dis. 2015;21:23-31.

126. Marena C, Zecca M, Carenini ML, Bruschi A, Bassi ML, Olivieri P, Azzaretti S, Locatelli F. Incidence of, and risk factors for, nosocomial infections among haematopoietic stem cell transplantation recipients, with impact on procedure-related mortality. Infect Control Hosp Epidemiol. 2001;22:510-7. 
127. Salvigni S, Piva S. Ventilation systems for hospital rooms devoted two immune compromised and/or infectious patients. Proc Indoor Air. 1993;5:569-74.

128. Withington S, Chambers ST, Beard ME, et al. Invasive Aspergillosis in severely neutropenic patients over 18 years: impact of intranasal amphotericin B and HEPA filtration. J Hosp Infect. 1998;38:11-8.

129. Dykewicz CA. Hospital infection control in haematopoietic stem cell transplant recipients. Emerg Infect Dis. 2001;7:263-7.

130. Raad I, Hanna H, Osting C, Hachem R, Umphrey J, Tarrand J, Kantarjian H, Bodey GP. Masking of neutropenic patients transport from hospital rooms is associated with a decrease in nosocomial Aspergillosis during construction. Infect Control Hosp Epidemiol. 2002;23:41-3.

131. Gayet-Ageron A, Iten A, van Delden C, et al. In-hospital transfer is a risk factor for invasive filamentous fungal infection among hospitalized patients with haematological malignancies: a matched case-control study. Infect Control Hosp Epidemiol. 2015;36:320-8.

132. Rikshospitalet: Daily work in protective isolation. 09/05/2005.

133. Rikshospitalet: for you to be a stem cell transplant. Guideline for adult patients and their families. 2006.

134. Solvang G, Sandset PM, Fjellet AL, Brubakk O, Hochlin K, Solheim N, Andersen BM. Protective isolation. In: Handbook of hygiene and infection control for hospitals. Oslo: Ullevål University Hospital; 2003. p. 128-31.

135. Wibbenmeyer L, Williams I, Ward M, et al. Risk factors for acquiring vancomycin-resistant Enterococcus and methicillin-resistant Staphylococcus aureus on a burn surgery step-down unit. J Burn Care Res. 2010;31:269-79.

136. Tuladhar E, Hazeleger WC, Koopmans M, Zwietring MH, Beumer RR, Duicer E. Residual viral and bacterial contamination of surfaces after cleaning and disinfection. Appl Environ Microbiol. 2012;78:7769-75.

137. Branch-Elliman W, Price CS, McGeer AM, Perl TM. Protecting the frontline: designing an infection prevention platform for preventing emerging respiratory viral illness in healthcare personnel. Infect Control Hosp Epidemiol. 2015;36:336-45.

138. Andersen BM. Pandemic flu. In: Handbook of hygiene and infection control in hospitals. Part 1 microbiology and infection control. Bergen: Fagbokforlaget; 2014. p. 212-36.

139. Morgan DJ, Murthy R, Munoz-Prize LS, et al. Reconsidering contact precautions for endemic methicillin-resistant Staphylococcus aureus and vancomycin-resistant Enterococcus. Infect Control Hosp Epidemiol. 2015;36:1163-72.

140. Banach DB, Bearman G, Barnden M, et al. Duration of contact precautions for acute-care settings. Infect Control Hosp Epidemiol. 2018;39:127-44. 